\title{
アルミニウム陽極酸化皮膜の接触電位差と 皮膜生成電压についで
}

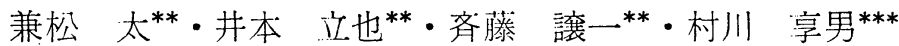

Relation between the contact potential of aluminum oxide films and film formation voltage*

UDC $669,716.91: 541.13$

KANEMATSU Futoshi**, IMOTO Tatsuya**, SAITO Joichi** and MURAKAWA Takao***

The contact potential of oxide films depended on the concentration of acid solutions. Further, when the anodic oxidation was performed under the constant current density, the film formation potential depended on the concentration of acid solutions. By comparing the contact potential and the oxide film formation potential, the following conclusions were made:

(1) As the film formation potential increased in the oxalic acid, the work function of the oxide films increased.

(2) If the magnitude of the steep rise in the oxidation potential was large, the work function of the oxide films became small when the sulfuric acid was used.

(Received November 8, 1973)

\section{1. 緒言}

陽極酸化皮膜の接触電位差 (C. P. D.) はその処理法の 違いにより，すなわち陽極酸化浴の組成を変えることに よつて異なる。それでは同一系で酸化浴濃度を変化させ た場合の C. P. D. はどうなるであろらか。定電流密度 で陽極酸化を行なつた場合，浴濃度が変化すれば皮膜生 成電圧も変化する。したがつてこの電圧変化に伴い，生 成される皮膜にも何らかの影響があるであろうし，この ため酸化皮膜の表面電気二重層が变化し，C. P. D.に影 響をおよぼす。

この報告においては, 酸化浴濃度変化に伴う皮膜生成 電圧の違いと C. P. D. との閒に何らかの相関関係があ るものと推定される。この相関関係が皮膜生成電圧の定 常状態域に対して生じるか，あるいは定常状態に至るま での電圧変化量に対して生じるかを検討するため以下の 実験を行なつた。

\section{2. 実験方法}

\section{1 試料およびその処理}

用いた試験片は高純度 $(99.995 \%)$ アルミニウムの
$20 \times 20 \times 1 \mathrm{~mm}$ の板で，その処理法，電解研摩，陽 極酸化等の条件は Table 1 に示す。

\section{2 実験装置}

C. P. D. 測定はイオン化法にもとづく装置で行なつ た。照合電極は U'nited States Radium Co. 製の $R_{a}{ }^{226}$ ，

Table 1 Test plate treatment.

Pretreatment alkaline degreasing $\left(\mathrm{Na}_{2} \mathrm{CO}_{3}+\mathrm{Na}_{3} \mathrm{PO}_{4}\right)$ detergent by distilled water acetone (Soxhlet's extractor)

Electrolytic Polishing $\mathrm{H}_{3} \mathrm{PO}_{4} 800 \mathrm{ml}+\mathrm{H}_{2} \mathrm{SO}_{4} 200 \mathrm{ml}, 5 \mathrm{~A} / \mathrm{dm}^{2}, 30^{\circ} \mathrm{C}$

Anodic Oxidation 2, 3, $4 \%-\mathrm{C}_{2} \mathrm{H}_{2} \mathrm{O}_{4}$ Solution, $\quad 1 \mathrm{~A} / \mathrm{dm}^{2}, 25^{\circ} \mathrm{C}$ $5,15,20 \%-\mathrm{H}_{2} \mathrm{SO}_{4}$ Solution, $1 \mathrm{~A} / \mathrm{dm}^{2}, 18^{\circ} \mathrm{C}$

Aftertreatment washed by distilled water hot distilled water and acetone (Soxhlets extractor)

* アルミニウム酸化皮膜の表面電位に関する研究 (第二報) Studies on surface potentials of aluminum oxide films (2nd report).

** 大阪市立大学工学部 (大阪市) Faculty of Engineering, Osaka City University (Osaka).

** 昭和電工株式会社 (東京都) Showa Denko K. K. (Tokyo). 
$5 \mu \mathrm{Ci}$ を用い, 直読法によつて測定した。極間距離は $1 \mathrm{~mm}$ とし，極間距離と C. P. D., イオン化電流，極間 抵抗の関係を Fig. 1 に示す。測定精度は土 $10 \mathrm{mV}$ であ る。測定雲囲気は $99.999 \%$ 乾燥チッソガス, 温度 $25 \pm 1$ ${ }^{\circ} \mathrm{C}$, 絶対温度 $6.5 \sim 7 \mathrm{kgH}_{2} \mathrm{O} / \mathrm{kgr}$. 乾燥空気。

酸化皮膜厚さの測定はエリプソメーター（島津製作所 製）によつて行なつた。

\section{3. 実験結果}

\section{1 シュウ酸陽極化皮膜}

Fig. 2 に示すように 3\%一処理皮膜では $100 \mathrm{~A}$ 付近か ら定常状態になるまでの C. P. D. は $2 \%$-処理に比べて かなり急激な変化をしており，600Aでの C. P. D は十 $200 \mathrm{mV}$ と $2 \%$-処理よりも約 $300 \mathrm{mV}$ プラス側へシフ トしている。一方，4\%-処理のものでは $100 \mathrm{~A}$ 付近か らの C. P. D. のプラス側シフトは $3 \%$-処理よりもさら に急激となつており， $600 \mathrm{~A}$ での值は $+1950 \mathrm{mV}$ と 2 $\%$-処理よりも約 $2,000 \mathrm{mV}, 3 \%$-処理よりも約 $1,700 \mathrm{mV}$ プラス側へシフトしている。この差は，2\%-処理一 $3 \%$ 一処理間の C. P. D. の差よりも，3\%-処理一 $4 \%$-処理 閒の C. P. D. の差の方が約 7 倍も大きく, 酸化浴濃度 が $1 \%$ 違つただけで C. P. D. はきわめて大きな差を見 せ， $4 \%$-処理以上で酸化皮膜のW．F は $4 \%$-末満に 比べてはるかに小さくなる。

一方, 皮膜生成電圧-時間曲線 (Fig.3) について見ると， Fig. 3 定常状態電圧は，2\%-処理，4\%-処理，3\%-処 理 の順に小さくなつており,C. P. D. の值が $2 \%$-処理 > 3

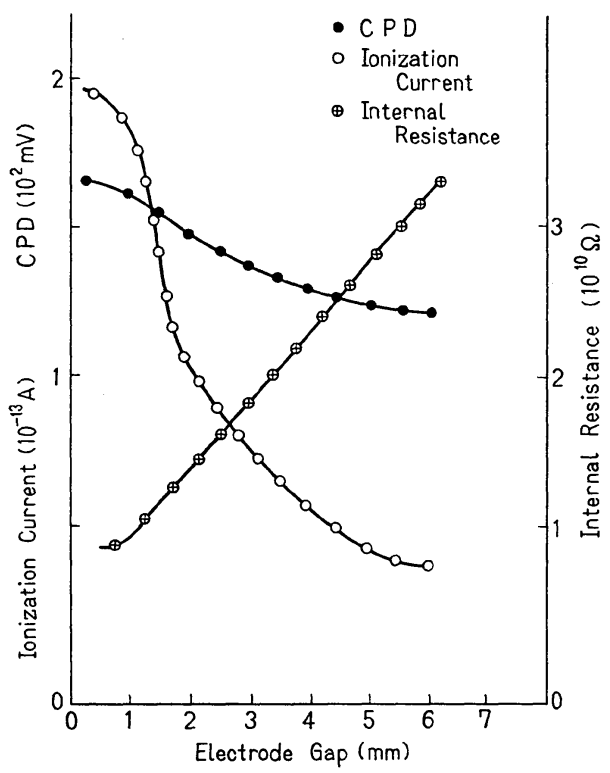

Fig. 1 Relationship between contact potential and electrode gap.
\%-処理> $4 \%$-処理の順 (C. P. D. は負になるほど大き く䧇るとしているため) であるのに対して異なつた結果 となつた。しかし, 定常電圧に至るまでの皮膜生成電圧 の変量は $4 \%$-処理> $3 \%$-処理> $2 \%$-処理の順となり, C. P. D. の值とは逆の順で相関する結果となつた。

\section{3 ?2 硫酸陽極酸化皮膜}

Fig. 4 に見られるごとく，5\%-処理皮膜におけるバ リヤタイプ皮膜からポーラスタイプ皮膜への移行過程の C. P. D. は $15 \%$-処理よりもはるかに急激な変化を示し ており， $600 \mathrm{~A}$ における值も $15 \%$ 処理よりも約 $2,000 \mathrm{~m}$ $\mathrm{V}$ プラス側へシフトしている。また $20 \%$-処理皮膜では 移行過程の C. P. D. 変化は15\%-処理よりも急激である が，5\%-処理に比べると小さい。 600 A での C. P. D. は +20 mV を示し，15\%-処理に比べて約 $500 \mathrm{mV}$ プ ラス側へシフトしている。15\%-処理と $5 \%$-処理皮膜閒 の 600 A における C. P. D. は， $15 \%$-処理と $20 \%$ 処-理 閒の約 4 倍にもなる。一方，Fig. 5 に示すように，皮膜 生成電圧は定常電圧状態において $5 \%$-処理> $20 \%$-処理 $>15 \%$-処理になつており， C. P. D. と皮膜生成電圧を

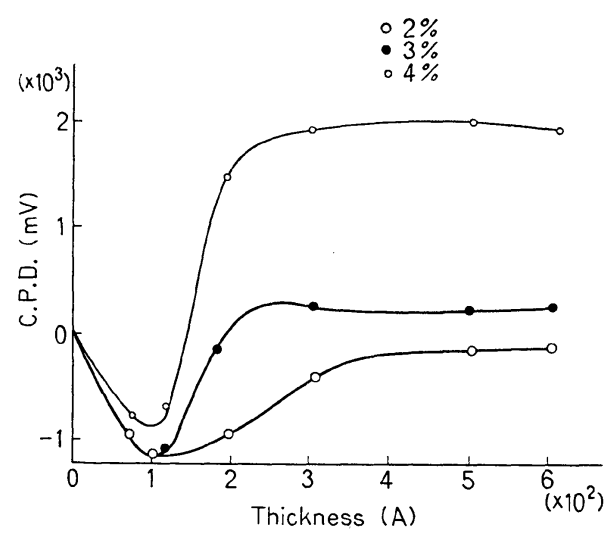

Fig. 2 Relationship between film thickness of aluminum oxide formed in various concentration oxalic acid solutions and contact potential difference in high purity nitrogen gas at $25^{\circ} \mathrm{C}$ under $15 \%$ humidity.

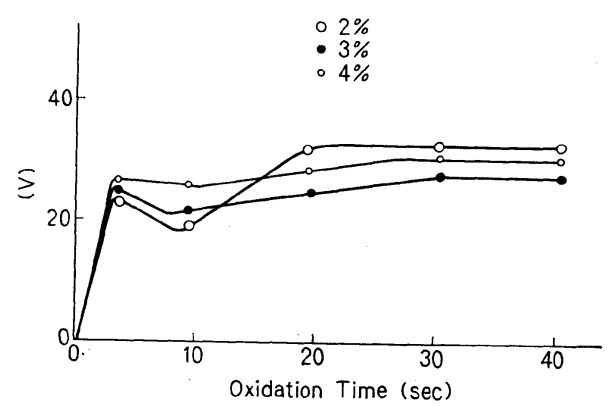

Fig. 3 Film formation voltage vs. oxidation time on anodic oxide films formed in oxalic acid. 
比べると, C. P. D. においては $15 \%$-処理 > $20 \%$-処理> $5 \%$-処理の順となつて抢り， C. P. D. と皮膜生成電圧 とは逆の順となつている。

\section{4. 考察}

陽極酸化皮膜中の孔の容積は生成電圧が高くなるにつ れて小さくなり，七ル数は減少する。しかしながらセル の大きさは大きくなる。接触電位差に影響をおよぼす因 子はセル数よりも孔の容積と思われる。すなわち単位体 積当りの結晶密度が接触電位差に影響を与えるものと考 えられる。なぜなら，仕事関数が不均一表面に関係する とき接触電位差はつぎのごとく取りあつかわれる。

I . 多結晶表面を持つ電導体を考え，各結晶画はそ机 自身二重電荷層を持ち，したがつて各々固有の仕事関数 を持つ!考えられる。つまり外見上外部電場の不在にお いて多結晶表面積に比して極めて小さい距離にある結晶 面の番目の外側の静電ポテンシャルはつぎのごとくな る。

$$
\varphi_{i \text { outer }}=-\bar{\mu} / e-\varphi_{i}
$$

$\varphi_{i}$ は結晶画の $i$ 番目の区画の仕事関数で, $\bar{\mu}$ は電導体内 側の電気化学ポテンシャルである。式(1)は $\varphi_{i}$, outer が仕 事関数の異なりによつて結晶面から結晶面へ変化するこ とを示す。しかしながら多結晶表面密度に比して充分に 大きな距離があると静電ポテンシャルは一定となり

$$
\bar{\varphi}_{\text {outer }}=\Sigma i f i \varphi_{i, \text { outer }}=-p / e-\bar{\varphi}
$$

となる。 $f i$ は $i$ 番目の結晶面が占める表面の 分率で, $\bar{\varphi}=\Sigma i f i \varphi i$ である。

II . 二つの導体間の多結晶面での電場が無視できるほ ぞ小さいと, 平衡状態は二つの導体の電気化学ポテンシ ヤルに相応して等しくなる。つまり

$$
\left(\varphi_{A}-\varphi_{B}\right)_{\text {ouuer }}=\bar{\varphi}_{B}-\bar{\phi}_{A}
$$

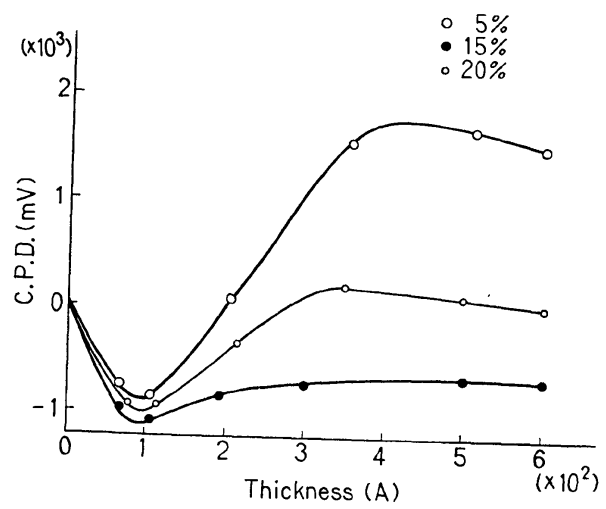

Fig. 4 Relationship between film thickness of aluminum oxide formed in various concentration sulfuric acid solutions and contact potential difference in high purity nitrogen gas at $25^{\circ} \mathrm{C}$ under $15 \%$ humidity.
で, 二つの多結晶表面の界面に存在するポテンシャルの 異汸りは平均仕事関数の異なりに等しい。

したがつて，アルミニウム陽極酸化皮膜においては(1) 式が考えられるが，測定表面積が $0.25 \mathrm{~cm}^{2}$ むの大きさ があることを考え合わせると(2)式が妥当であ万う。した がつて接触電位差は平均仕事関数の異なり，すなわち(3) 式が適用される。流ぜなら，測定表面積に比してアルミ ニウム陽極酸化皮膜表面の各結晶表面での静電ポテンシ ヤルは平均化されているものとみてさしつかえない。し たがつて陽極酸化法の違いによる表面状態等の異字りに 扎いても，接触電位差は(3)式で考えてさしつかえないで あろら。一方, 単位体積当りつ結晶密度が小さくなると 表面電気二重層の平均注小さくなり, 結晶密度が大きけ れば平均は大きくなるであろう。したがって C. P. D.は 密度が大きくなるほどエネルギーバリヤは高くなるであ ろらから大きく流る。それゆえ結晶構造が均一な酸化皮 膜が最も大きな C. P. D. を示し, 結晶構造が不均一に 汸るにしたがつて C. P. D. は減少するであるう。

シュウ酸処理皮膜においては, 皮膜生成電圧の定常電 压域の電圧の大きさから考えると C. P. D. 変化は $2 \%$ 処理> $4 \%$-処理 > $3 \%$-処理の順が考えられる。ところ が実験結果における C. P. D. 変化は $2 \%$-処理>3\%処理 > $4 \%$-処理の順となつて㧍り定常電圧域の順とは 異なる。一方, 定常電圧に至るまでの電圧変化を見ると $2 \%$-処理> $3 \%$-処理> $4 \%$-処理の順となり C. P. D. 変化の順序と相関している。したがつて，この皮膜にお いては表面電位は定常電圧の状態の大小よりも陽極酸化 開始から定常電圧に到達するまでの電圧変化の大きさに よつて左右されるものと考えられ, 電圧変化幅が小さい ほど接触電位は小さくなるものと考えられる $($ Fig. 6)。

硫酸処理皮膜に扔いて注電圧変化は $5 \%$-処理>15\%処理 $>20 \%$-処理の順となつており, 電圧が変化する時 間も $5 \%$->15\%->20\%-処理つ順であるが陽極酸 化 開 始時から最高電圧に到達するまでの初期電圧変化は $5 \%$

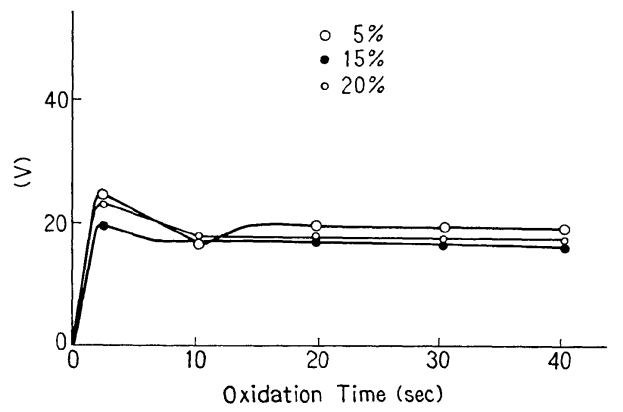

Fig. 5 Film formation voltage vs. oxidation time on anodic oxide films formed in sulfuric acid solutions. 


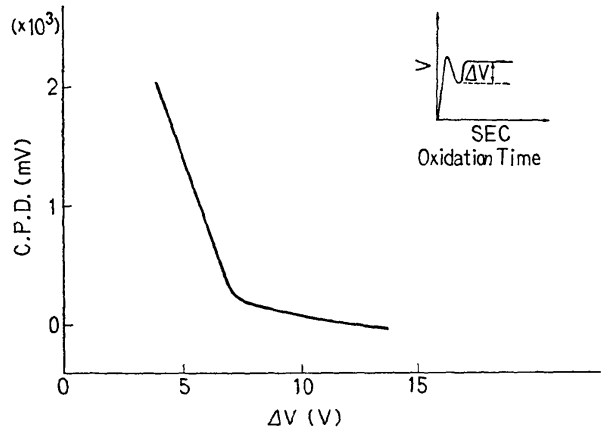

Fig. 6 Variable quantity of film formation voltages between initial states and constant states vs. contact potential difference.

一処理 $>20 \%$-処理 $>15 \%$-処理の順で, C. P. D. 変化は 15\%-処理>20\%-処理＞ $5 \%$-処理の順である。したが つて, この皮膜においては単位体積当りの密度の大小， およびポーラスタイプ皮膜への移行過程の長さ等より も，バリヤタイプ皮膜からポーラスタイプ皮膜への移行 開始点の電圧量によつて酸化皮膜の表面電位は影響を受 ける。すなわち移行開始点でのポーラスタイプ皮膜の基 盤生成密度がそのまま表面電位に現加れるものと考えら れ，この電圧量の順と C. P. D. の順は Fig. 7 に見られ るごとく逆の順で相関しており, 移行開始点電圧が高い ほど接触電位は小さくなるものと推定される。

\section{5. 結言}

以上のごとく，陽極酸化皮膜の接触電位差は定電流密

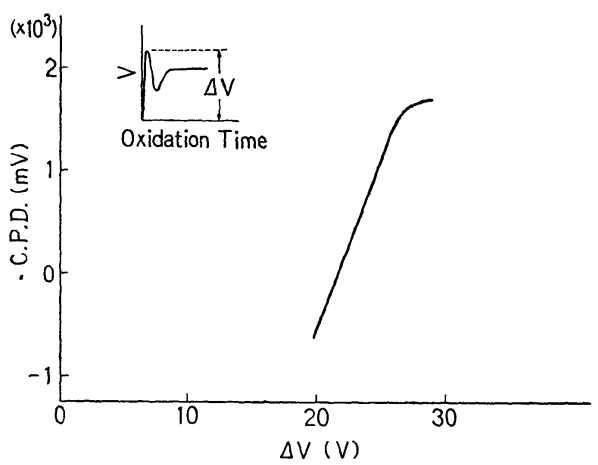

Fig. 7 Variable quantity of film formation voltages at rising states vs. contact potential difference.

度で酸化処理したときの電圧の大きさに関係して変化す るが，その影響する電圧の領域は電解質の種類によつて 異なり, シュウ酸処理では定電圧に至るまでの領域と関 係し，その電圧変化が大きいほどアルミニウムに対する 接触電位差は大きいが，4\%処理以上では逆に小さくな る。また硫酸処理の C. P. D. 汇関係する電圧変化領域 は酸化開始直後の初期電圧領域にあり，そのときの電圧 の変化が大きいほどアルミニウムとの接触電位差は小さ くなる傾向となった。

\section{参 考 文 献}

1）井本，兼松，斉藤，村川：軽金属，23（1973）, 528. 